Santa Clara Law

Santa Clara Law Digital Commons

Faculty Publications

Faculty Scholarship

$1-1-1988$

\title{
Teaching Feminist Legal Theory at Texas: Listening to Difference and Exploring Connections
}

Patricia A. Cain

Santa Clara University School of Law, pcain@scu.edu

Follow this and additional works at: http:// digitalcommons.law.scu.edu/facpubs

\section{Recommended Citation}

38 J. Legal Educ. 165

This Article is brought to you for free and open access by the Faculty Scholarship at Santa Clara Law Digital Commons. It has been accepted for inclusion in Faculty Publications by an authorized administrator of Santa Clara Law Digital Commons. For more information, please contact sculawlibrarian@gmail.com. 


\title{
Teaching Feminist Legal Theory at Texas: Listening to Difference and Exploring Connections
}

\author{
Patricia A. Cain
}

Feminists who talk about teaching methods ask each other the following sorts of questions: Is there such a thing as feminist pedagogy? As feminists and law teachers, what should we be doing in our classrooms to reflect our understanding that "the personal is political"? Now that we have conquered the issue of sexist language (at least in our own classrooms); now that we have proved ourselves sufficiently to consider breaking down the classroom hierarchy; now that we are present in more than token numbers (at least in some institutions); now that we have instituted courses and teaching materials that do not ignore women; and now that we, in the footsteps of our feminist colleagues in other academic disciplines, have broken the research barriers by publishing feminist articles, is it not time to give more attention to what we do when we teach? Is it not time to focus on the connection between feminist theory and teaching method? 1

My recent experience in teaching a seminar in Feminist Legal Theory has helped me make some important connections between teaching, knowledge, and feminism. The experience was so different from my other law teaching experiences and my students' previous classes that, before offering observations on the place of feminist pedagogy in the law school, providing a detailed account of the class seminar (including my students' records of their reactions to the course ${ }^{2}$ ) may be helpful.

Patricia A. Cain is Professor of Law, University of Texas.

1. I do not mean to suggest that I am the first to raise these questions or even to suggest answers. Feminist pedagogy was certainly part of the agenda at the 1985 Critical Legal Studies Conference on Feminism. It was also the focus of the final panel at the recent Women in Legal Education AALS Workshop in Washington, D.C., October 22-24, 1987; see especially the presentation by Catharine Hantzis entitled "Kingsfield and Kennedy," reprinted in $38 \mathrm{~J}$. Legal Educ. 155 (1988). I only mean to suggest that the inquiry regarding feminist teaching method is in the early stages compared with the inquiry regarding feminist content in the law school curriculum.

For further discussion of feminist pedagogy in the law school context, see Toni Pickard, Experience as Teacher: Discovering the Politics of Law Teaching, $33 \mathrm{U}$. Toronto L.J. 279 (1983) and Jennifer Jaff, Frame-Shifting: An Empowering Methodology for Teaching and Learning Legal Reasoning, 36 J. Legal Educ. 249 (1986).

2. The most compelling part of this teaching experience for me was reading the student journals. At the end of the course, I returned the journals to my secretary for distribution to the students together with a memorandum from me explaining that $I$ would like to either keep the journals or make xerox copies of those portions the students were willing to share with others. Most of the journals are intensely personal, and, as such, cannot be shared with anonymous readers in any detail. Furthermore, each 
In the spring of 1986, after twelve years of teaching courses in federal taxation at an institution that has never made "Women and the Law" or "Sex-Based Discrimination" a regular part of the curriculum, I offered a three-hour seminar entitled "Feminist Legal Theory." Seminars at Texas are typically "closed out" at twelve or thirteen students. Higher enrollment would not only destroy the quality of the small group experience but would make it virtually impossible for the professor to offer individualized feedback on student participation and writing. After reading the student petitions to enter my "closed" seminar, I made the first of several political decisions that semester. I opened the course and abandoned the individual writing project. The course "closed out" the next day at twenty-six students.

The class was scheduled to meet once a week for fourteen weeks. The assignment for the first week was entitled "What is Woman?" The readings included: ${ }^{3}$

1. Genesis 1-15 (the story of Adam and Eve)

2. 1 Corinthians 11 (Paul's message of why women but not men should cover their heads when they pray; man as the image and glory of God, woman as the glory of man)

3. Plato's Republic, excerpts from Book V (his proposal to end private families and to make qualified women guardians just like the men)

4. Aristotle, On the Generation of Animals (excerpts) (discussion of males as active and females as passive, etc.)

5. Hume, "Of Chastity and Modesty," from Treatise of Human Nature

6. Rousseau, "Marriage," from Émile

7. Kant, "Of the Distinction of the Beautiful and Sublime in the Interrelations of the Two Sexes"

8. Bradwell v. Illinois, 83 U.S. 130 (1873), ${ }^{4}$ and Justice Bradley's concurrence 5

entry holds additional significance for me because I knew the student writing it, a significance I cannot share by the mere repetition of the entry. The journals could not have been written as they were had we not, as a group, developed a high level of trust. The excerpts I have chosen are intended to indicate the existence of that trust without breaching it.

3. In choosing these readings, I was guided by the selections included in Philosophy of Woman: An Anthology of Classic and Current Concepts, ed. Mary Briody Mahowald, 2d ed. (Indianapolis, 1983) [hereinafter Philosophy of Woman].

4. The majority opinion held that the Illinois Supreme Court's denial of Myra Bradivell's application for a license to practice law solely on the basis of her female sex did not violate the privileges and immunities clause of the Fourteenth Amendment. The holding was consistent with the decision-one week earlier-in the Slaughter-House Cases, 83 U.S. (16 Wall.) 36 (1872), that the right to practice one's trade was not a "privilege" or "immunity" protected by the Fourteenth Amendment.

5. Justice Bradley dissented in the Slaughter-House Cases, supra note 4 . Thus, having held earlier that the privileges and immunities clause did protect one's right to pursue one's chosen vocation, he was forced to find some other ground for denying Myra Bradwell the right to pursue hers. He wrote in part:

[The civil law, as well as nature herself, has always recognized a wide difference in the respective spheres and destinies of man and woman. Man is, or should be, woman's protector and defender. The natural and proper timidity and delicacy which belongs to the female sex evidently unfits it for many of the occupations of 


\section{The First Class}

Because the class size had increased from twelve to twenty-six in the week before classes started, we had to move from the originally assigned small seminar room to a regular classroom. Although the classroom was small, its arrangement was inappropriate for the atmosphere I wished to create. The students were out there in their fixed desks and I was in front of them as the deliverer of knowledge, not part of them but apart from them. Although I could sit at a desk and be part of them, the podium at the front of the room seemed a constant reminder of where I was expected to be. ${ }^{6}$

So there I was in the first meeting of the class that had so totally occupied my thoughts from the moment of its conception, staring out from my position at the podium into twenty-six faces (twenty-four female and two male), all but two of whom were virtual strangers. Not knowing my own seminar students in advance was a strange experience for me. Usually I teach students tax in their second year and then have some of them as seminar students in their third year. But I had been teaching in California the preceding year, and, although this was my second semester back at Texas, only two of the students in this seminar had been in my tax classes. Why were they here, these strangers? What did they expect? Were they even feminists?

\section{Excerpts from Student Journals}

-I came into this seminar not knowing what to expect, and feeling rather nervous. First, I have no idea what "feminism" is, and the thought of spending the next few months with a bunch of radical bra burners is a little frightening. I support "women's rights" and am incensed by discrimination as much as anyone. But I have to ask myself if I am a fake. After all, I have never been denied the opportunity to do anything I wanted to do. I have lived fairly comfortably and after I graduate from law school, will be enjoying the kind of life most people never dream of. So I do not understand what it is that "feminists" are so angry about, not really. Since the feminist movement really got underway when I was still being bottle fed, it is likely that I am now benefitting from the sacrifices others made before me and would not feel so contented had I grown up 20 years earlier. I hope that this class can help me see what it is all about.

-I have rejected feminism as I have experienced it up until now. It didn't seem to have anything to do with me. Housewives who were sick of cleaning house and caring for their kids but who would be perfectly happy to hire someone who looked like me to clean the house for them. Many minority women were already working outside of the home and caring for children already. What did the women's movement have to offer them? Our voices are heard in the movement now. Where is the movement going, though? Diverse women with diverse views and diverse goals. Conservative, liberal, radical. Yet we talk about "women's concerns" as if there is some sort of consensus. Do we want what men have? Do we want to change the system?

civil life. . . The paramount destiny and mission of woman are to fulfil the noble and benign offices of wife and mother. This is the law of the Creator.

Bradwell v. Illinois, 83 U.S. 130, 141 (1873).

6. All future classes were held in a different room with tables and chairs that could be moved to suit our taste. It did not escape anyone's notice that each week the students who arrived early took it upon themselves to rearrange the furniture from its disconnected, hierarchical structure (tables and chairs facing a podium in front of a blackboard) into a more connected arrangement. 
-You ask "What is Feminism?". I think that that may be as difficult to answer as a question like "What is Life?" The answer depends completely upon who you are asking and even when you are asking. If you asked my friend E-, I am sure she would have some wonderfully slick answer about freeing down-trodden women (E-never says "girls") from the shackles of male dominance. E- is militant. Not because she wants to be free of shackles, but because she sees shackles everywhere. She looks for them in every action, every sentence and waits hungrily for the chance to rant and rave about subservience. If $\mathrm{E}-$ is a "feminist," then I am not nor do I wish to be classified in that group. Fortunately, while E- may be a feminist, I don't believe she is the only feminist. . . E E- thinks I am mush, fluff. She thinks that the fact that I wear dresses is cute . . . I, however, do not think I am "fluff." I truly believe that one can be feminist without being militant. I have always been reluctant to call myself a feminist because every feminist I know is like E-. Even in 1986 we still think "libber" and "bra burner" when we hear "feminist" and I really don't think I want to be thrown into that category. In fact, I used to think that I had to choose between feminist and feminine. . . . Today I am not so sure. . . . I hope that as this course gives me exposure to more feminist issues and ideas, I can reconcile this apparent conflict within me between femininity and feminist-ity. I hope so, because I kind of like myself as a feminine feminist.

-The problem is that the word "feminist," in the eyes of many, brings to mind a radical, trouble-making, man-hating woman. Many of my friends who share the same values and beliefs that I do regarding women would never consider themselves feminists. ...

-And when I walked past the three males, they all stared rudely. Then I heard a lone male voice "You know what I think of when I see big tits like that?" . . . Said loudly ... . for them, I wasn't even there. . . . I felt violated, sick to my stomach and more than a little angry. Not like when I read [Rousseau or Kant]. No, this was much more personal. So I still do get angry when I am violated by men. And that's what makes me a feminist. Feminism is not a word I can define in dictionary terms. It's feelings and emotions and a way of being, a way of life. . . . For me, being a woman means being feminist; it's all I know of life.

I began the lecture with "The Circle," a teaching device I had learned from my feminist colleagues in other departments. I drew a large circle on the board and then turned to the class and said, "This is all the people in the world." Then I drew a line that cut the circle in half, marking one half with an "M" and said, "This half is all the men and this half is all the women." Next I drew a line that cut the " $\mathrm{M}$ " half down to a third and said, "This is all the white men in the world." Then I shaded in a tiny sliver of this portion and said, "This is all the educated and privileged white men in the western world." After a slight pause, I turned to face the class and said, "For most of you, this is what you know about the world."

I continued my lecture: "Certainly this is what Justice Bradley knew about the world. The natural and proper timidity of the female sex, the delicacy of the female sex, the decision and firmness of the male sex, the sterner sex, these are the things Justice Bradley knew about the world."7 The class had begun.

\section{See supra note 5 .}

[I]n my opinion, in view of the peculiar characteristics, destiny, and mission of woman, it is within the province of the legislature to ordain what offices, positions, and callings shall be filled and discharged by men, and shall receive the benefit of those energies and responsibilities, and that decision and firmness which are presumed to predominate in the sterner sex.

Id. at 142 (Bradley, J., concurring). 
To introduce the concept of stereotyping and how it works at a personal level, I announced to the class that we were about to do an experiment to help us understand how Justice Bradley had formed his concept of woman. First we talked about how we know that certain things are what they are: a chair, a table, a room. The sets of properties that we extract from the general concept are called schemata in certain theories of social cognition. ${ }^{8}$ I suggested that we do a schema of a particular type of person: a gay male. I passed around blank index cards and asked everyone to write down whatever words or phrases they thought of when they thought of gay male. The words could be good or bad, it did not really matter. No one would know who had written what. The point was to be honest in one's reactions and to see whether we did stereotype and whether we did so in similar ways.

I had chosen "gay male" to see if any subtle homophobic attitudes showed up. They did not. Instead, the list of words and phrases, apart from the expected mention of AIDS, was positive. "Well-dressed," "mustaches," and "friend of women" occurred most frequently. Not one student had suggested a race or color for this abstract "gay male." I asked whether that meant they had envisioned men of all races and colors. Most people shook their heads. What did that mean, I asked. Did that say something about the category "gay male"? Or did it say something about themselves as members of their own specific races?" Did it say something about their assumptions about race in general? When they thought of "professional woman," what race did they envision? What race did they envision when they thought of "welfare mother"? When Justice Bradley spoke of the "natural and proper timidity and delicacy" of women, whom did he have in mind? What of the frontier women who had plowed the fields alongside the men? What of black slave women, such as Sojourner Truth, who had been lashed and had worked long hours in the fields?

I was able to refer to the exercise throughout the course to help us guard against the presumption of race, the presumption of class, and the one presumption that seemed to occur more often than any of the others: the heterosexist presumption. ${ }^{10}$ By the end of the course, students were able to call each other on their own biases. Consider the following student dialogue:

FIRST STUDENT [in context of class discussion on abortion]: It isn't fair. Men never worry about birth control. I mean don't they even care? Finally, I asked one of them, "Why don't you ever ask?" And he said it was because he knew I wouldn't risk it. Really, how could he know? At best he could only guess ... and that leaves women with two choices: take full responsibility or claim celibacy!

8. I am indebted to Joyce McConnell for this exercise. See her remarks from the SALT joint miniworkship on "Racism, Sexism, Classism, and Heterosexism: A Close Look at Our Biases in the Law School Classroom," AALS Annual Meeting, New Orleans, January 1986 (tape available from the AALS, transcript available from author).

9. Although the class was predominantly white, $20 \%$ of the students were women of color. Both males were white.

10. I do not recall ever calling anyone on a presumption of sex. "We," when used by the students, tended to mean all of us in the room, although I often wondered whether some of the female students consciously pictured the men in the room when they said "we." If a student meant "we women," she usually said so explicitly. 
[Slight Pause. Second Student looks at professor before speaking.]

SECOND STUDENT: Only two choices? Don't you want to reconsider that statement?

FIRST STUDENT [in a defeated whisper]: The heterosexist presumption again.

\section{The Second Class}

The assignment on "What is Woman?" continued. Additional readings included excerpts from Simone de Beauvoir's The Second Sex ${ }^{11}$ and bell hook's "Black Women and Feminism."12 The students were asked to complete the following written assignment: "Write a one page critique of either Rousseau or Kant. Your critique can challenge either the philosopher's basic premise or his internal logic (or both)."

When we met next, we sat around a group of large tables so that we made a circle. I asked four students to read aloud their critiques of Rousseau and Kant. After each reading, we discussed briefly which basic premises had been attacked and whether the critiques also contained attacks on the internal logic of the excerpts we had read. All four papers were entirely rational, written in the detached voice of a lawyer.

The fifth student's paper had a somewhat different tone. She expressed outrage at the absurdity of what the male philosophers were saying. ${ }^{13}$ After noting the difference in tone, I pointed out that law school seemed to have had its desired effect and congratulated the first four students on their ability to think abstractly, to be cool and detached, in sum, to think like a lawyer. Nonetheless, I confessed some amazement at the lack of emotion. Then I had all the students write down one word describing how they felt when they read the assignment for the first week.

This simple exercise changed the class's entire dynamic. Imagine, if you can, twenty or so composed law students around a large table; the student to my left starts off: "My name is A-, and I felt embarrassed." "My name is $\mathrm{J}$ - , and I felt angry." "My name is $\mathrm{S}-$, and I felt amused." "My name is T-, and I felt uncomfortable." Only two students expressed rage or anger. The second time around the circle, I asked the students to elaborate on their feelings, if they were so inclined. Immediately, we leapt from the past of Kant and Rousseau to the present, to this law school, to this class.

It was at this point that I made my second political decision. I abandoned

11. Simone de Beauvoir, The Second Sex (New York, 1952).

12. bell hooks, Ain't I a Woman: Black Women and Feminism (Boston, 1981), ch. 5. See especially id. at 159-160, which presents Sojourner Truth's "Ain't I a Woman" speech challenging the stereotype of women as the delicate sex in its original context.

13. Rousseau, for example, argues that women were made to please men and thus must be trained properly to do so, and further, that men can get on without women better than women can get on without men. Thus, women's education must be "wholly directed to their relations with men." Philosophy of Woman, supra note 3, at 182.

Kant argues that the virtue of woman is a beautiful virtue and that of man is noble. He then continues: "Woman is intolerant of all commands and all morose constraint. They do something only because it pleases them ... . I hardly believe that the fair sex is capable of principles." Id. at 196.

To the extent Kant is saying that women are naturally moral and thus need not respond to principles and obligations in the way that men must, he might be heralded as the forerunner of cultural feminism. A closer reading of Kant, however, reveals the misogyny that underlies his belief that women are merely beautiful and men are noble. 
the rest of the assignment and committed the class time to pursuing what was happening at that moment, spontaneously and openly. I am not trained to do group therapy, but I had learned as a teacher and as Ghair of the Faculty Grievance Committee of the University of Texas how important it could be to listen and to validate. I encouraged the entire class to practice listening.

I have a theory about listening, really listening, and I tried to impart it to the students. Often when we listen to others, we pick out the bits of their stories that are like our stories and discard the rest. That is, we embrace the familiar, the part that is easily recognized. At other times, especially at the first hint of the nonfamiliar, we say "that's not like me at all." I asked the students not to discard any part of each other's stories, not to contrast themselves to each other. For the rest of the class, I asked them to identify with the speaker and to do so beyond the familiar part. My theory is that if you can find some slim reed of commonality with the other, you can begin to build understanding. But to find the slim reed, you cannot focus on yourself when listening to the story of the other. Instead, you must so identify with the other that you feel the story being told.

The students continued to talk about their feelings. A black woman spoke about how she felt others in the class would look to her for the black woman's perspective on life every time she spoke, and how, if she continued to feel that way, she would not speak. Being a black woman, she continued, meant that being black comes before being female. A Jewish woman said she identified herself as Jewish first and female second and told a story about summer camp and why being Jewish mattered. A Chicana explained how her view of women had been shaped by growing up in a world of strong women. A man in the class talked about his inability to take criticism from women, how it was more difficult for him to admit being wrong in front of women than in front of men. Finally, the entire class began to talk about how it feels to make mistakes and about the pressure in law school to say the correct thing at all times. We talked about mistakes we had made. No one judged. No one contrasted. Everyone listened.

By the end of the class hour, a bond of trust had been established. No one wanted to leave the room. We knew that we had created a safe place in which all of us could talk personally and be heard. I left the classroom that day knowing that something special had happened. I wondered how I could best preserve the trust. And I wondered how I could encourage the students to connect "the personal" to the legal issues $I$ intended to pursue throughout the rest of the course.

\section{Excerpts from Student Journals}

-At first, I was embarrassed by other people talking so openly. I can't do that. I felt
so uncomfortable, I thought about dropping the class, but something stopped me.
I'm glad I stayed. By the end of the semester I was comfortable.

-I couldn't believe that was a law school class. None of us could. We walked around the halls all week asking each other: what happened? what's going on? is this real?

-Going around the room stating our names and saying whatever we wanted created a special bond between the members of our class. I was very affected by several 
women who said they were black or chicana first and women second. They also felt that the feminist movement was a white, middle class female movement. I had never thought of this before but I can see their point.

- The whole point of this journal entry is to say that up until this semester and this class, I've been consumed by ME: Women's issues only as they affected me and not beyond. Lately, however I've felt so good, pointing my concerns outward, instead of just in on me. It feels like college, when you used to think and really care about others and not be in competition with them. And it feels good.

\section{The Third Class}

The topic for the third session was "What is Feminism?" The assigned reading included some historical material on the first wave of feminism, ${ }^{14}$ as well as some excerpts from the work of modern-day feminists. ${ }^{15} \mathrm{We}$ did not lose the trust that had been established in the last class. I had been concerned that three students who had been absent might feel excluded from the bond that had been established because they had not been there to experience its genesis. I began the class by acknowledging my concern and explaining the dynamic of the last class.

We then explored the various categories of feminism, from liberal to radical, and attempted to build a working definition on which we could all agree. Focusing on oppression turned out to be the key. No one wanted to argue for equality as a goal. We had not yet begun the readings on equality, and yet it was clear already that there would be disagreement about the meaning of the term. By contrast, everyone could agree that there was oppression in the world. To the extent feminism was committed to the eradication of all forms of oppression, all the students felt they could call themselves feminists. The means that could best accomplish the agreedupon end would be our next focus.

\section{Excerpts from Student Journals}

-I had never identified myself as a feminist before, but of course I think oppression is bad. If feminist means ending oppression then I approve. But how will it end it? I'm not sure I understand that yet.

-I especially liked the part about consciousness raising being the method of the feminist movement. ${ }^{16}$ I think listening to women's experiences is the first step, especially in law school where the viewpoint is so male.

\section{The Fourth Through Thirteenth Classes}

During this part of the course we focused on the legal concept of equality, looking first at how the concept has evolved in race and sex cases decided by the Supreme Court. After reading the basic cases upon which

14. E.g., Carol Hymowitz \& Michaele Weissman, A History of Women in America, chs. 5-7 (New York, 1978).

15. bell hooks, Feminist Theory: From Margin to Center (Boston, 1984), ch. 2, entitled "Feminism: A Movement to End Sexist Oppression," was the selection students found most helpful. As background reading for this class, I also relied on Josephine Donovan's Feminist Theory: The Intellectual Traditions of American Feminism (New York, 1985).

16. Catharine MacKinnon makes this point in Feminism, Marxism, Method and the State: An Agenda for Theory, 7 Signs 515 (1982). 
modern-day equal-protection doctrine is founded, we began to consider various feminist critiques of the Supreme Court's position on sex discrimination. ${ }^{17}$

We tried to build our own working model of equality, rejecting at an early stage the basic assimilationist model under which differences are erased and the values of the predominant group (i.e., white males) are adopted by everyone. We considered variations of the pluralist model under which differences are retained and equally valued. The variation that won the most support was similar to what Alice Rossi calls the "hybrid" model, ${ }^{18}$ a melting pot of values in which everyone, including white males, makes changes. ${ }^{19}$

Because we were focusing on socially constructed differences based on sex, our model employed an androgyny scale, represented by a single long line moving from "extremely male" to "extremely female" values. ${ }^{20}$ The scale was used to demonstrate that the accomplishment of equality under the assimilationist model would entail chopping off the female end of the scale and moving everyone up to the male end. Under the pluralist model, the scale was pictured as a backdrop on which numerous individual circles were distributed from the female end to the male end. Each circle symbolized a single group of persons with shared values. The circles did not overlap. To demonstrate the concept of equality using the hybrid model, a number of the previously drawn circles were connected within a long oval. In other words, in our ideal world, people in the "male" circles would be stretched toward the female end of the androgyny scale and people in the "female" circles would be stretched toward the male end. Androgyny does not mean cutting off the male and female ends and placing everyone in the

17. Suggested commentary included Ann Freedman, Sex Equality, Sex Difference, and the Supreme Court, 92 Yale L.J. 913 (1983); Herma Kay, Models of Equality, 1985 U. Ill. L. Rev. 39; Sylvia Law, Rethinking Sex and the Constitution, 132 U. Pa, L. Rev. 955 (1984); Kathryn Powers, Sex Segregation and the Ambivalent Directions of Sex Discrimination Law, 1979 Wis. L. Rev. 55; Stephanie Wildman, The Legitimation of Sex Discrimination: A Critical Response to Supreme Court Jurisprudence, 63 Or. L. Rev. 265 (1984); Wendy Williams, The Equality Crisis: Some Reflections on Culture, Courts, and Feminism, 7 Women's Vol. Rts. L. Rptr. 175 (1982); Note, Toward a Redefinition of Sexual Equality, 95 Harv. L. Rev. 487 (1981); Catharine MacKinnon, Sexual Harassment of Working Women: A Case Study of Sex Discrimination (New Haven, 1979).

18. See Alice Rossi, Sex Equality: The Beginnings of Ideology, in Voices of the New Feminism, ed. Mary Lou Thompson, 59 (Boston, 1975).

19. For a discussion of various models of equality as they might apply to treatment of pregnancy, see Ann Scales, Towards a Feminist Jurisprudence, 56 Ind. L.J. 375 (1980-81). Professor Scales, for example, differentiates between the assimilationist view, which would ignore pregnancy because it is not a male attribute (women simply cannot be assimilated while pregnant), and the liberal view, which would recognize pregnancy as a difference but accommodate it only insofar as it can be compared with the male norm, e.g., as a disability.

20. The "male" value versus "female" value dichotomy was a natural outgrowth of our reading of excerpts from Carol Gilligan, In a Different Voice (Cambridge, 1982). Related nonlegal readings included Nancy Chodorow, The Reproduction of Mothering: Psychoanalysis and the Sociology of Gender (Berkeley, 1978), and Nel Noddings, Caring: A Feminine Approach to Ethics and Moral Education (Berkeley, 1984). 
center. As Fran Olsen has argued, androgyny should be viewed not as a world of gray but of reds and blues and greens. ${ }^{21}$

During the last weeks of the course, against the various models of equality, we analyzed cases I call the "hard cases." Specific topics included rights of putative fathers, ${ }^{22}$ the combat exclusion, ${ }^{23}$ statutory rape, ${ }^{24}$ abortion, ${ }^{25}$ single-sex institutions, ${ }^{26}$ affirmative action, ${ }^{27}$ pregnancy in the workplace, ${ }^{28}$ new reproductive-technology issues, ${ }^{29}$ divorce and property divisions, ${ }^{30}$ the legal concept of sexuality, ${ }^{31}$ and sexual torts. ${ }^{32}$ Throughout

21. Frances E. Olsen, The Family and the Market: A Study of Ideology and Legal Reform, 96 Harv. L. Rev. 1497 (1983).

22. Parham v. Hughes, 441 U.S. 347 (1979) (upholding a Georgia statute that prevented a father of an illegitimate child from recovering for the child's wrongful death); Caban v. Mohammed, 441 U.S. 380 (1979) (striking down a New York statute that gave the mother but not the father of an illegitimate child the right to veto adoption); Lehr $v$. Robertson, 463 U.S. 248 (1983) (rejecting putative father's claim that failure to give him notice of child's adoption violated his constitutional rights).

23. Rostker v. Goldberg, 453 U.S. 57 (1981) (upholding the male-only draft registration).

24. Michael M. v. Superior Court, 450 U.S. 464 (1981) (upholding a California statutory rape law that punished males but not females).

25. Roe v. Wade, 410 U.S. 113 (1973), and Maher v. Roe, 432 U.S. 464 (1977) (sustaining a Connecticut statute that funded childbirth and medically necessary abortions but not elective abortions).

26. Mississippi Univ. for Women v. Hogan, 458 U.S. 718 (1982) (striking down the female-only admissions policy of a state nursing school).

As a recipient of an excellent education at a woman's college in the 1960s, I argued in class in favor of such institutions. My arguments were met with vehement opposition. It was a time that called for me to listen. Said one student journal: "[I]s not the goal of feminism to train people away from cultural bias so that 'masculine' and 'feminine' traits are more evenly distributed among the sexes? Coeducation at formerly single-sex institutions is valuable for this because it thrusts one sex into an environment dominated by the other, thereby forcing a reevaluation of gender roles on both sides of the fence. If women are allowed into men's space but not men into women's, the likelihood of any 'ideal' person emerging free of stereotypes is greatly reduced."

27. Regents of Univ. of California v. Bakke, 438 U.S. 265 (1978) (reverse discrimination on the basis of race subjected to strict scrutiny), and Kahn v. Shevin, 416 U.S. 351 (1974) (upholding Florida tax exemption available to widows but not to widowers) and Schlessinger v. Ballard, 419 U.S. 498 (1975) (upholding preferential rule for female naval officers, giving them a longer period to obtain promotion than their male counterparts). But see, Two v. United States, 471 F.2d 287 (9th Cir. 1972), cert. denied 412 U.S. 931, rehearing denied 414 U.S. 882 (1973) (female officer argued that the rule was actually detrimental).

28. At the time, Cal. Fed. was before the Supreme Court. It has since been decided. California Federal Savings \& Loan Ass'n. v. Guerra, 107 S. Ct. 683 (1987).

29. My colleague John Robertson gave a guest lecture that focused on ethical and legal issues, such as who should have access to new techniques, e.g., in vitro fertilization, and who has ownership rights in the extra eggs.

30. Isabcl Marcus, SUNY Buffalo, gave a guest lecture based on her study of New York equitable-division laws and the resulting feminist critique.

31. Mary Dunlap, activist lawyer in San Francisco, and Isabel Marcus gave a dual presentation on a Saturday morning that drew nearly perfect attendance. They spurred a discussion that continued long past the noon cutoff time and created an atmosphere of positive energy and caring. I highly recommend using other feminists as guest lecturers so that students can be exposed to a number of "different voices." The student journals reflected their appreciation of my having broadened the students' listening experience in this way.

32. Mary Dunlap discussed her participation in Barbara A. v. John G., 145 Cal. App. 3d 369, 193 Cal. Rptr. 422 (1983) (woman, who suffered an ectopic pregnancy was forced to undergo surgery to save her life that rendered her sterile, brought suit against man who impregnated her, claiming she consented to sexual intercourse, relying on the man's knowingly false representation that he was sterile). 
the discussion of law, we would stop periodically to look at certain underlying assumptions about the role of women. We read excerpts from works that allowed us to talk about women's bodies and clothes, ${ }^{33}$ the heterosexual dating regime, ${ }^{34}$ and how we and our friends felt about sex, abortion, and motherhood. ${ }^{35}$

It has been claimed that women think differently from men, that we learn better if we are able to start with the particular and build to the abstract. ${ }^{36}$ A further claim is often made: The "particular" that women build upon best is our own personal experience. ${ }^{37}$ But I find that all students, male and female, have a better understanding of abstract material once they are able to relate it to their personal experience in some way.

My major pedagogical goal in this part of the course was to encourage the telling of personal stories about what it meant to be female or male; what it meant to be black, brown, or white; what it meant to be living in a heterosexist society. The aim was to emphasize that a person's point of view is naturally determined by that person's life experiences. I felt that if we failed to articulate the things that contributed to our point of view, we would all stay in our separate little circles on the androgyny scale. If we talked and listened, we might begin to stretch ourselves along the scale. And if we were to continue to talk and listen upon becoming lawyers, we might help to stretch others.

For the professor, the difficulty of encouraging the telling of personal stories is that it is impossible to know in advance what the stories will be or even if they will be relevant to any of the legal issues under study. Allowing the stories to be told independent of any structure may lead to the professor's losing control. On the other hand, setting up a structure that is too confining may destroy the atmosphere of free association and, as a result, someone's story may be lost.

Like all teachers I know and have observed, I have a tendency to control classroom discussion. If I judge a student's comment irrelevant, I will say so and move on. Although I may be more flexible than many teachers, I keep a constant guard against discussions that become too tangential. To protect against my own tendency to control and dominate the class discussion, I used the nonlegal readings to stimulate the telling of personal stories. For

33. Susan Brownmiller, Femininity 23-51, 79-102 (New York, 1984).

34. Margaret Mead, Male and Female 281-95 (New York, 1975).

35. See generally Adrienne Rich, Of Woman Born (New York, 1976).

36. See generally Mary Field Belenky, Blythe McVicker Clinchy, Nancy Rule Goldberger \& Jill Mattuck Tarule, Women's Way of Knowing: The Development of Self, Voice, and Mind (New York, 1986). "Most of the women we interviewed were drawn to the sort of knowledge that emerges from firsthand observation, and most of the educational institutions they attended emphasized abstract 'out-of-context learning."' Id. at 200.

37. One's personal experience not only informs one's "knowing" at the answer stage; it also affects the very questions that are asked and upon which knowledge is built. "In considering how to design an education appropriate for women, suppose we were to begin by simply asking: What does a woman know? Traditional courses do not begin there. They begin not with the student's knowledge but with the teacher's knowledge. The courses are about the culture's questions, questions fished out of the 'mainstream' of the disciplines. If the student is female, her questions may differ from the culture's questions, since women, paddling in the bywaters of the culture, have had little to do with positing the questions or designing the agendas of the disciplines." Id. at 198. 
example, selections from Male and Female prompted the telling of dating stories. I began with a story of growing up in Columbus, Georgia. Girls there joined social clubs at an early age - the "Wee Sub Debs" in the fifth grade, for example. The ninth-grade club (the "Junior Sub Debs") held a social each month, and members who did not ask a date had to pay a fine. I still cringe at the memory of being turned down by a boy in my Latin class who said he would be out of town that weekend but instead showed up with another date. The stories, I explained, did not have to be related to each other or even to the law. The point was to share something that crossed our minds as we read the assignment for that class.

The procedure for sharing stories was to go around the circle. No one was ever pressured to speak, but each knew she or he would have a chance. Most important, what she or he had to say would not be determined by whoever took the floor first. This was not an exercise in manipulating one's thoughts to fit the subject at hand. Nor was it an exercise in putting aside irrelevant thoughts in order to stay with someone else's flow of conversation. It was an exercise in saying right now in the present anything that the speaker had to say, anything that the speaker thought was important.

In law school we are trained to build arguments. It is sometimes useful to tell stories. Later, when we build our arguments, we will have more stories upon which to draw. In a law school that is committed to student diversity, we ought to help create the space for our students to benefit from that diversity. We ought to encourage them to listen to one another.

\section{Excerpts from Student Journals}

-I've been thinking about our second class session some more. The major lesson I've drawn from that session, which continues to stick with me, is to pay attention to my feelings. . . . Not worrying about being right all of the time has made me be more free to speak up in Business Associations, Advanced Con Law, and other classes . . . I think I am learning more from others. Instead of working out the repartee while "listening" to others, I find myself really listening to and understanding others. For example, the discussions in our 4th amendment Con Law class have been much more lively for me. Each student has a set of experiences that brings a varying perspective to the search and seizure cases. I like my increased awareness of classmate interaction.

-Today's class discussion about the readings was great. And I suppose you noticed, too, how everybody sort of schlepps along when we do cases and, you know, legal stuff, but then when we shift to a $\mathrm{CR}^{98}$ sort of mode, everybody perks up and the energy level just soars . . . A word about that: I can't speak for anybody else, but for me, when we do legal stuff, well, it's just sort of like any other class. And that's not bad; I've enjoyed law school, on the whole. . . It's just that the CR part of class is such a . . a luxury, an indulgence. All those emotions and feelings and sensitivities which I've professionally pruned and clipped these three years get shaken free and it's great.

\section{The Last Class}

Several weeks before the end of the semester, I broke the class into four smaller groups. Each group was assigned one of the Supreme Court cases that had generated the most disagreement in class discussion: Parham $v$.

38. Consciousness-raising. 
Hughes, ${ }^{39}$ Michael M., ${ }^{40}$ MUW v. Hogan, ${ }^{41}$ and Rostker v. Goldberg. ${ }^{42}$ At the time the groups were formed, they were given the following instructions: You are the Court of Final Appeal (above the Supreme Court). The assigned case is appealed to your court. How do you decide? The following rules apply: (1) The only cases appealed to your Court are cases involving a violation of the equal-protection and due-process clauses of the Constitution. (2) The Constitutional amendment creating the Court of Final Appeal states that "the Court shall have broad power to issue orders that are in the national interest provided they are necessary and proper to preserve the principle of equality under which this country was founded." (3) You must do your best to render one unanimous decision. The decision should state what the principle of equality is, whether it is violated in the case before you, and what your order(s) is (are). (4) This is your first case, so you are not bound by any precedent. You will, of course, consider additional cases, for which this first case will be precedent.

The results of the first case were reported in the final class. All groups had been able to reach unanimous decisions. ${ }^{43}$ Unanimity, however, proved more difficult to obtain in their next case, a case assigned on the final class day.

The final assigned case was the Ninth Circuit opinion in Johnson $v$. Santa Clara County, 44 an affirmative action case, which at the time was on appeal to the Supreme Court. ${ }^{55}$ Johnson, a male employee, initiated the case to challenge his employer's affirmative action plan when the employer, despite a unanimous recommendation of Johnson by his supervisors, promoted a female candidate for a position instead. The facts of the case suggested that the male candidate was slightly more qualified than the female candidate because he had scored higher on a preliminary examination. ${ }^{46}$ Johnson had also been the first choice of the reviewing panel of supervisors. Nonetheless, unstated but obvious considerations suggest that the decision-making process favoring the male candidate was tainted with bias. ${ }^{47}$ Most of the students however, viewed the issue as one of

39. See supra note 22.

40. See supra note 24.

41. See supra note 26.

42. See supra note 23.

43. Parham v. Hughes, supra note 22, apparently caused the most difficulty. One student reported: "Perhaps more than anything else, this assignment taught me how difficult the job of an appeal panel is. Each group member had a unique perspective from which to view the facts of this 'male discrimination' suit. It took a long time for us to kick around the facts enough so that we could agree on a common approach. Even then, one person dissented. We coaxed her along and she eventually signed on with us. But even that process of trying to persuade someone with a substantially different approach, yet a similar result, felt a bit unsettling."

44. 770 F.2d 752 (9th Cir. 1985).

45. The case has subsequently been decided. Johnson v. Transportation Agency, 107 S. Ct. 1442 (1987) (upholding the affirmative action plan).

46. Johnson scored 2.5 points higher than Joyce, the female candidate. In the overall rankings, Johnson tied for second place on the exam, Joyce was the next highest scorer after Johnson. Id. at 1448.

47. The exam was oral and was administered by males. The recommendation of Johnson was made by an all-male panel. The female candidate, Joyce, had managed to score above other men despite the "maleness" of the job environment (she was a road- 
whether affirmative action plans should be upheld if they were used to promote less qualified women over more qualified men. The split in the class occurred along two lines: (1) how the students viewed the facts, and (2) how they felt about affirmative action.

We had discussed Bakke $e^{48}$ earlier in the semester, but our final discussion of affirmative action was qualitatively different. Most of the students of color in the class spoke out about how it felt to have one's credentials constantly doubted-if you are black or brown it is assumed that you only got where you are because of affirmative action. Most of the white women in the class had difficulty thinking of themselves as beneficiaries of any affirmative action plan because law schools have not had special admissions plans for women. I, by contrast, have lived in a world without affirmative action, in which I was denied employment for which I was clearly qualified, ${ }^{49}$ as well as in a world with affirmative action, in which it is often rumored that we women law professors have been hired solely because we are women. ${ }^{50}$

A significant number of the women in the class were appalled at the thought that anyone should be forced to hire less qualified women. We talked some about the slipperiness of standard "qualifications." We even talked directly about the admission of certain law students with lower LSAT's than other candidates. One of the male students who had written a diatribe against affirmative action earlier in the semester admitted he was in the process of changing his mind.

As we focused on the Johnson case, we talked about how the law, in its conservatism, tries to remedy social problems by making changes too late in the process. The reversal of the decision in Johnson after it had been initially decided in favor of the male came too late, said some. The Court, argued the students, should demand a different affirmative action plan, one under which the problem of perceived special treatment for women would not arise. Others expressed anger that anyone could view this set of facts as a case of "special treatment." When a male reviewing panel in a predominantly male institution decides in favor of a male candidate, does that not raise a presumption of special treatment in favor of the male candidate?

maintenance worker and $97 \%$ of her coworkers were male). That the affirmative action officer's recommendation of Joyce was followed, rather than the reviewing panel's recommendation of Johnson, does not mean that the ultimate decision maker viewed the male candidate as more qualified. Indeed, it just as easily suggests that, after closely reviewing the situation, in light of all the facts, he viewed the female candidate as more "qualified."

For further discussion of the perception of who was more qualified in the Johnson case, see Martha Minow, The Supreme Court 1986 Term Foreword: Justice Engendered, 101 Harv. L. Rev. 10, 46-47 (1987). The Supreme Court itself realized that the determination of "qualifications" was inevitably subjective. 107 Sup. Ct., at 1457 n.17.

48. See supra note 27.

49. In 1969, in London, I applied to several American companies for jobs whose only prerequisite was the equivalent of a college education. I never made it past the paper application stage and once was told directly that the company hired women only as secretaries.

50. Barbara Babcock has the best retort to this charge that I have heard. When asked how it felt to be given the job as head of the Civil Division of the Justice Department just because she was a woman, she replied, "A heck of a lot better than it would feel not to be given the job just because I am a woman." 
Why is it, someone asked, that affirmative action is always perceived as "special" treatment instead of "just" treatment?

Affirmative action, special treatment, inequality-these were all legal notions we had discussed before. But this discussion was richer. In some ways, it was also easier in that it was more spontaneous. Having such good practice talking each week made difficult issues less difficult to discuss. And yet at the same time it was harder. It was harder because we really listened to the people who had been cast as second-class citizens by affirmative action, because we heard their pain, their anger. It was harder because those of us in the room with high credentials and white skin were forced to reconsider our own notions of what "qualified" means.

Consensus was impossible. Many were unwilling to support affirmative action as a general principle, having just listened to the voices of people who had been victimized by it. Others felt strongly that affirmative action was the only workable means for obtaining a just society in the long run, and that the short-term costs would simply have to be borne by those of us participating in the present process. Everyone agreed that more dialogue was necessary. As one student wrote in her journal, "I was overwhelmed by a sense of loss when this class let out. We've got to keep the dialogue going. I don't know exactly what it's doing for law today, but it's making better lawyers for tomorrow."

\section{Excerpts from Student Journals}

-At first it bothered me that the woman in the case got the job after making one phone call to the affirmative action officer. Then I thought about the good ole boy system and how over the years men have gotten jobs through their connections.

-We talked about affirmative action and I wanted to share with everyone that I am here at UT because of affirmative action. I'm sure some people in the class already "knew" that. It has a psychological effect on me sometimes. "Do I belong here?" I ask myself. I have to answer "no." Obviously I don't. Obviously I couldn't get in without a helping hand. Someone who was worthy of UT didn't get in because I did. . . The psychological effect on me is not negative. . . . I have done well at UT. . . . I have not struggled here. So what does it mean? . . . To me it means that the measures we use are wrong. The tests are arbitrary. A white male with my LSAT scores and grades could have come here and done very well. I believe that. The people I'm outgrading here are the people he would outgrade-the people who, according to the tests, belong here. . . . It's all so arbitrary and yet we talk about it as if it's meaningful and it frustrates me. I felt this frustration when we met in our groups to discuss our disposition of the Johnson case. They didn't understand my preoccupation with concerns about the fact that the exam was oral, my questions as to who composed the examining board, questions about the process in general. They said those questions had nothing to do with whether affirmative action should be upheld here. They have everything to do with it as far as I'm concerned. They are inextricably tied. . . . Affirmative action has been the only thing that has made significant changes for minorities (including women) in this country. Not equal opportunity, not equal rights, not equal treatment, but equal result. . . . So now I have to argue with a white male who is the victim of reverse discrimination. A victim of his own system. Even if his arguments are right, how can I give up that which has created a substantive change? . . . Affirmative action has (had?) substance but it's being twisted now. It's an evil.

-Our group had no problem getting a consensus on the first case. The Johnson case was more difficult. And this led to the class discussion about affirmative action plans, some of which surprised me. It is interesting to observe how the tools for redressing discrimination acquire negative qualities even in the eyes of those they are supposedly 


\begin{abstract}
designed to help. Again, I must marvel at the tremendous power brought to bear against the processes of change. That the focus can be shifted from the total exclusion of women from skilled positions (in Johnson) to one woman's actions (analogous to invoking a good ole boy network) as the basis for challenging the Affirmative Action plan of the company involved, which from the facts seems little more than a piece of paper anyway, is astounding. But I suspect it is the symbolic power represented by the existence of the plan that is really at issue. I would love to know how no "evidence of past discrimination" was established. I would like to suggest that those processes which are most vehemently denounced by patriarchy are our greatest strengths because they represent the real potential for change. That is precisely why the system seeks to eradicate them. Affirmative action has never been a reality in the sense that the goals represented are far from being achieved. But it is potentially a threat because it builds in the requirement and the expectation of change. It is visible. Do people really believe that unqualified women and minorities get hired because of affirmative action? I think we are hearing the newest sophisticated version of racism and sexism. I also think the real dynamic is that very qualified women and minorities don't get hired with or without it.
\end{abstract}

\title{
Conclusion
}

I began this essay by noting that my experience in teaching this seminar led me to make some important connections between teaching, knowledge, and feminism. Those connections, in turn, have led me to give more thought to pedagogical techniques that I identify with feminist methodology, especially the technique of listening to each other's personal stories. As this essay has shown, such listening can be fostered in a number of ways:

1. Assign readings that can be used as springboards for sharing personal experiences.

2. Do not try to control the telling of personal stories by insisting they relate to each other or to the legal material assigned. (Many such connections are difficult to see in advance, and even if stories are not related to this class, they are still valuable.)

3. Take risks. Tell your own stories and be willing to think out loud in class.

Do these techniques work? Yes, of course they work. The students in Feminist Legal Theory told their personal stories and listened to each other. From their comments to me, it is clear that the experience was quite unique for them in law school and that the experience was valuable.

I do not mean to suggest that the telling of personal stories should supplant rigorous legal analysis or that my pedagogical techniques are appropriate in every class. But I do believe that law schools should create more opportunities for such exchanges between students and that law professors should work to listen better to their students. Teachers who do not know whom they are teaching or what is already in the minds they are trying to reach start off with a significant handicap.

Finally, if there is no course in the curriculum that either allows the pursuit of feminist issues or the connection of students' personal stories to their learning of the law, I encourage you to explore creating such courses. My own experience has enriched the rest of my teaching (yes, even my teaching of tax law). And, although I had doubts throughout the semester about whether I could accomplish all that I had set out to accomplish, by the end of the semester I knew the experiment had been a success. 


\section{Final Entries in Student Journals}

-As a final note, I'd like to comment upon the entire semester. When this class was great, it was really great! On some days, especially when discussing legal issues like Title VII, we did not have the time to go into enough background to have the best discussion we could have had. But on the whole, we got to forget the normal bounds of law school thinking, and do a little exploring on our own. That was nice. I also met a few more kindred spirits: they're few and far between in this place, so you've got to treasure the ones you find.

-I would like to thank you for offering this course this semester. I want to let you know that I feel this was my favorite and most worthwhile course in my three years in law school. I know you are considering narrowing the scope of the course in the future to avoid "spreading ourselves too thin." I want to express my appreciation of the wide scope of the course. I was exposed to many topics I feel are important and will never get the opportunity to examine those issues in quite the same way again. I hope to read and learn more about the ... areas we have touched upon this semester. When a course instills that desire and interest, it is a rare experience.

-Every hour I spent in your class, you were teaching at least two other persons not then present. My sister, with whom I live, should get class credit. My door-opening sexist friend (whom I mentioned a few pages ago) heard everything second hand every Thursday. And countless others have heard bits and pieces. This was not a unique situation-all of us spread what we learned to our peers. And we won't forget.

-I was interested but skeptical about what this course would be about. Initially I thought it was going to be a typical "white woman's" discussion of the plight of the middle-class, Anglo women's movement. On some days, I would leave class feeling that my initial thoughts were reinforced. Luckily, overall this was not the case. . . This course was excellent. I met women here who I never would have exposed myself to. . . . You gave me support, objective discussion, and even more you listened to the opinion of a "woman of color."

-It felt so good to talk about and dredge up and confront this stuff. It wasn't forced, the admissions and personal revelations were freely given and accepted in trust. When did we quit valuing vulnerability and start putting a premium on manipulation. You know, it's meetings like these (no, "meeting" is too impersonal and cold, how about "sharings"?), when they're juxtaposed against the rest of the law school curriculum, that make one despair of how much of my insides have been dried up by the posturings and singlemindedness of the law school game. Law school's made me forget, even ridicule, thinking about how "caring" and "emotion" ought to factor into life. That's just not a part of the legal process. This class has made me remember.

-This class was very special. Many of us shared a sense that something we looked forward to each week was now at an end, at least in a structured sense. I cannot think of anything more profound in life than to impact another human being's life in a positive and lasting way. And that is precisely what you and this seminar did. 
HeinOnline -- 38 J. Legal Educ. 1821988 